Supplement of Clim. Past, 14, 473-514, 2018

https://doi.org/10.5194/cp-14-473-2018-supplement

(C) Author(s) 2018. This work is distributed under

the Creative Commons Attribution 3.0 License.

(c) (1)

Supplement of

\title{
Arctic hydroclimate variability during the last 2000 years: current understanding and research challenges
}

\author{
Hans W. Linderholm et al. \\ Correspondence to: Hans W. Linderholm (hans.linderholm@gvc.gu.se)
}

The copyright of individual parts of the supplement might differ from the CC BY 3.0 License. 


\section{Supplementary material}

Table S1 Information of 12 CMIP5 climate models used in this study. The spatial resolution of atmosphere is expressed by the number of longitudinal grid cells $\times$ the number of latitudinal grid cells.

\begin{tabular}{llc}
\hline Model & Institute/Country & Spatial resolution of atmosphere \\
\hline GFDL-CM3 & NOAA GFDL/USA & $144 \times 90$ \\
GFDL-ESM2G & NOAA GFDL/USA & $144 \times 90$ \\
GFDL-ESM2M & NOAA GFDL/USA & $144 \times 90$ \\
GISS-E2-H & NASA GISS/USA & $144 \times 90$ \\
GISS-E2-R & NASA GISS/USA & $144 \times 90$ \\
HadGEM2-AO & MOHC/UK & $192 \times 145$ \\
HadGEM2-ES & MOHC/UK & $192 \times 145$ \\
MIROC5 & MIROC/Japan & $256 \times 128$ \\
MIROC-ESM & MIROC/Japan & $128 \times 64$ \\
MIROC-ESM-CHEM & MIROC/Japan & $128 \times 64$ \\
MRI-CGCM3 & MRI/Japan & $320 \times 160$ \\
NorESM1-ME & NCC/Norway & $144 \times 96$ \\
\hline
\end{tabular}

5
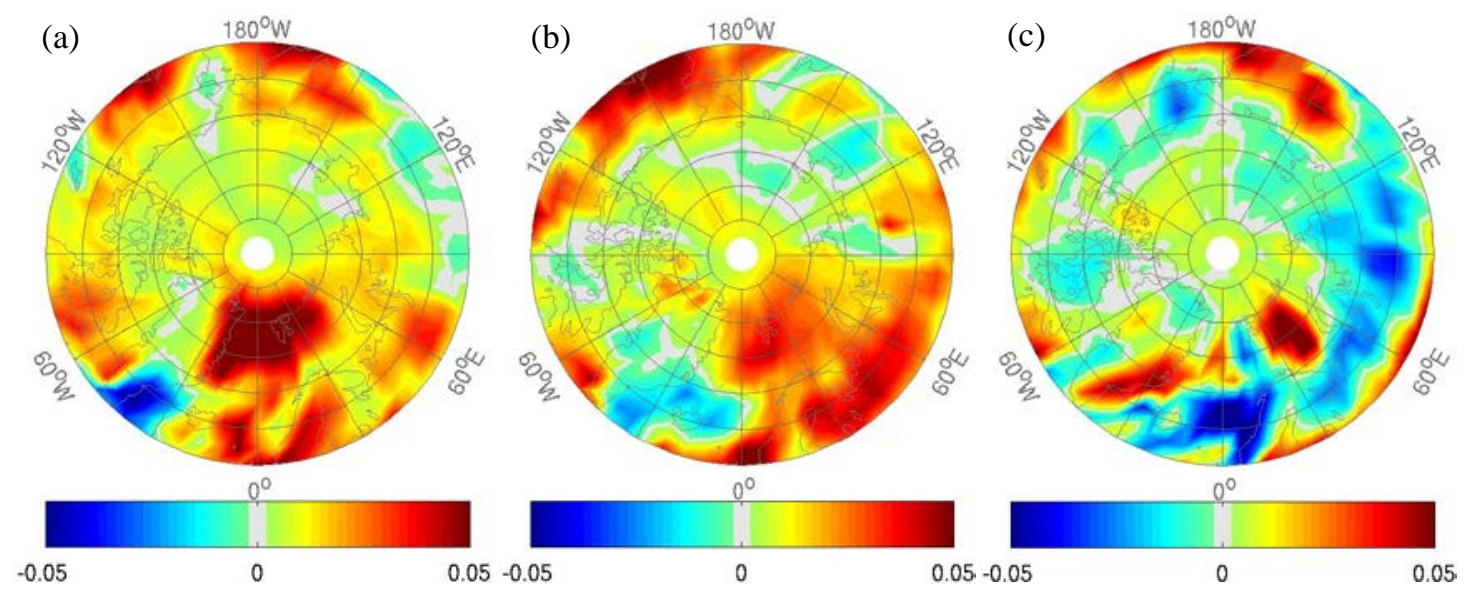

Figure S1. Spatial pattern of differences in annual hydroclimate between MCA (950-1250) and LIA (1450-1850) based on (a) HadCM3, (b) IPSL-CM5A-LR and (c) MPI-ESM-P last-millennium simulations. The values are the standardized annual total precipitation. 


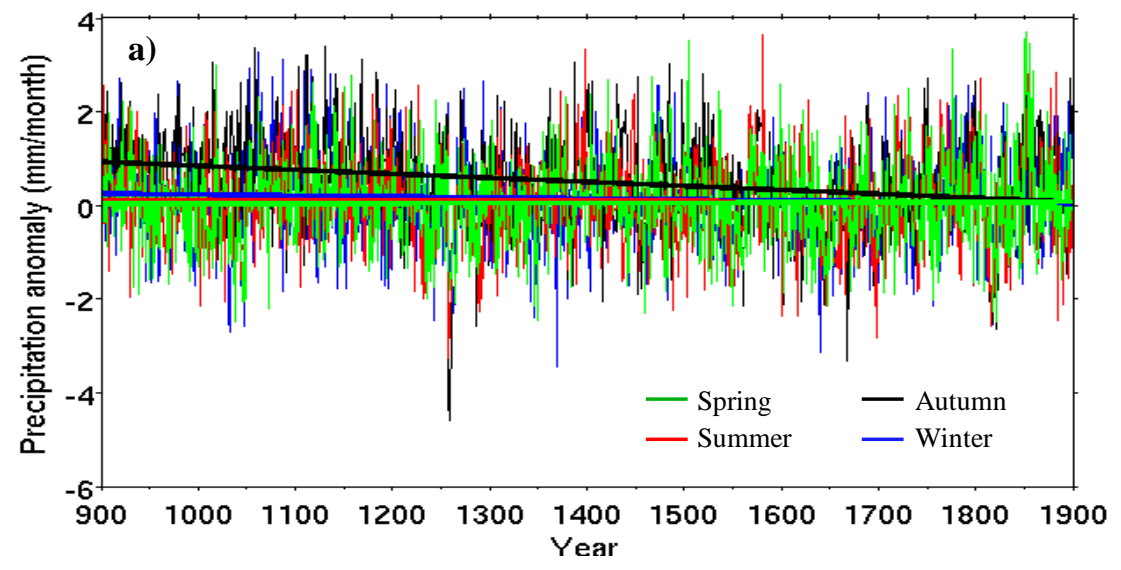

b)
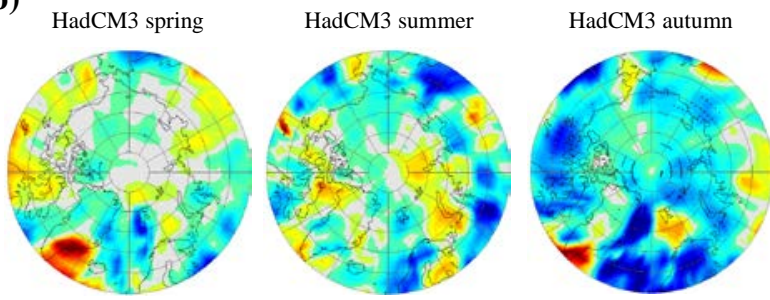

HadCM3 winter
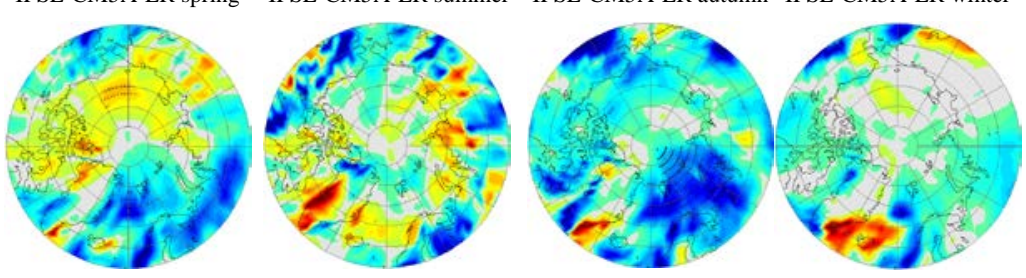

MPI-ESM-P spring

MPI-ESM-P summer

MPI-ESM-P autumn
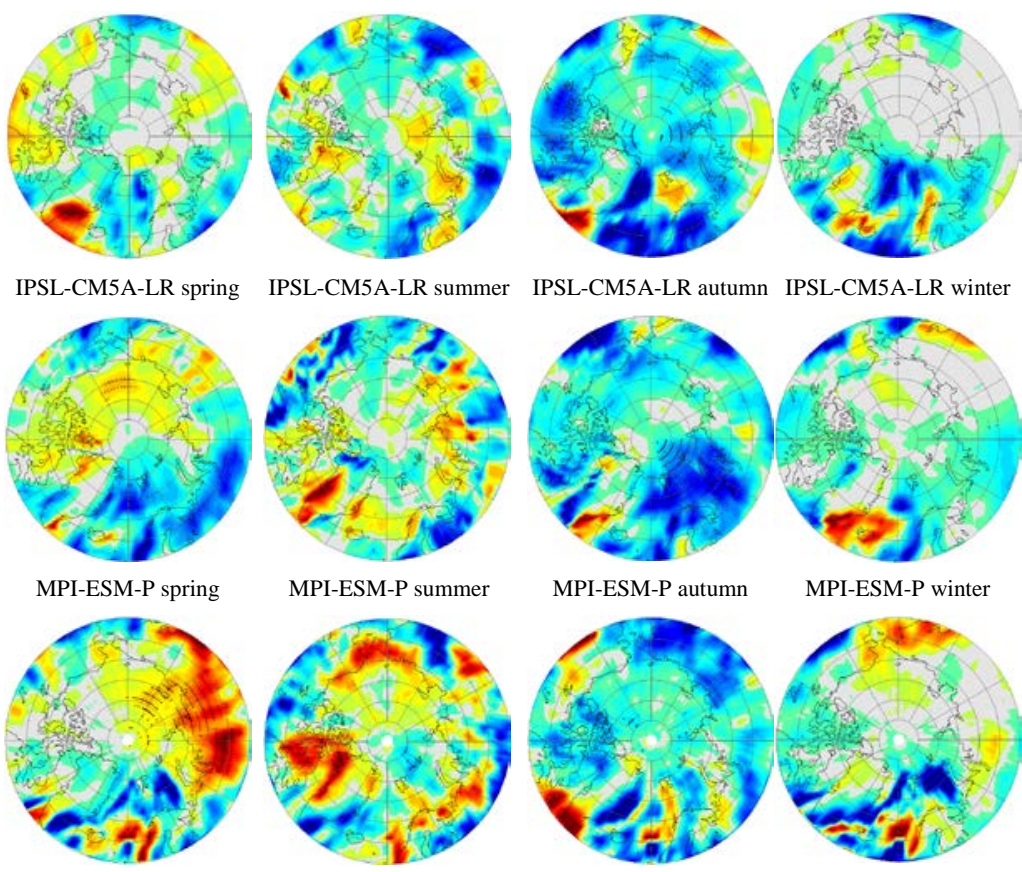

MPI-ESM-P winter

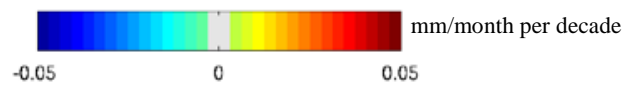

Figure S2. a) Variability and linear trends of the Arctic spring, summer, autumn and winter total precipitation anomalies (900-1900 CE) from 3-model (HadCM3, IPSLCM5A-LR and MPI-ESM-P) ensemble mean. b) Spatial patterns of linear trends in seasonal total precipitation anomalies over (900-1850 CE) from 3 climate models. Dots mark grids where the trend is significant $(\mathrm{p}<0.01)$. 